\title{
Cross-specialty training in the era of competency-based education
}

See the related commentaries by Warnock and Miles (p. 367) and Vinden and Ott (p. 369) and the discussion paper by Caron and colleagues (p. 419)

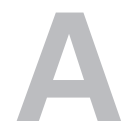

$\mathrm{n}$ article discussing a proposed curriculum to provide surgical training to family physicians is included in this issue of the journal. ${ }^{1}$ We decided to publish it with accompanying commentaries for and against the proposal in order to facilitate an informed debate. The argument for enhancing the surgical skills of family physicians is that they could provide surgical care for patients in remote locations, where surgeons may not be based. ${ }^{2}$ Those against the proposal question its premise; patients in remote areas have remarkably good access to surgical care and they expect the same standard of care as patients elsewhere. ${ }^{3}$

The proposal comes at a time when specialty training is undergoing change. Rather than designing a training program as a time-based process for the sequential acquisition of knowledge and skill, it is suggested that progression of surgical training should depend on the acquisition of defined competencies. The Royal College of Physicians and Surgeons of Canada has given this transformation the name "competence by design" (CBD). While CBD implementation currently deals with postgraduate medical education (residency), the intention is to include the postcertification career training currently referred to as "continuing professional development" (CPD). One promised aspect of CBD is that it will permit surgeons to tailor their education to fit the practice required in their particular situations. Some surgeons will restrict their practices to areas of special interest (e.g., arthroplasty, hepatobiliary surgery); others will undertake cross-specialty training to expand their competencies (e.g., cesarian section performed by general surgeons). Where then does this proposal to train family physicians to undertake major surgery fit in the era of CBD?

Competence by design removes the element of time but does not alter the other fundamentals of training. All course modules have 4 elements: prerequisites, a learning phase, testing and maintenance of competence. Currently, the prerequisites for a trainee to undertake advanced surgical training is successful completion of the Principles of Surgery (POS) course and examination. While some credit should be given to certified family physicians, the proposal would need to include additional training and testing in the fundamentals of surgery to meet the validated prerequisite standard. Competence by design will accommodate a practising surgeon learning a new procedure where established surgical skills facilitate the acquisition of new skills. On the other hand, there is no reason to believe that nonsurgeons, even if they have completed POS, would become competent more quickly than residents in training. If this is true, the curriculum for enhanced surgical skills cannot be completed within a year. More likely it would take the same effort and time as a conventional surgical training program - without the determined checks and balances of a certified training program. Patients and regulatory authorities expect physicians with surgical privileges to have passed standard tests of competence. Testing of cross-specialty competencies should remain within the responsibility of the subspecialty. Testing the wide range of competencies proposed in this curriculum will be logistically difficult. Training and testing within the time frame proposed is impossible. Finally, maintenance of competence has 3 elements: practice of the specific skill, practice of related skills and CPD. The premise of the proposal is that insufficient volumes of work are available in remote areas to maintain conventionally trained surgeons. In this situation, the family physician will be unable to maintain competence by practice of the specific or related skills and will have to spend an inordinate amount of time undertaking coursebased CPD.

Provision of surgical services in a country as large as Canada requires collaboration between several levels of government, hospital authorities and several medical specialties. While the lack of a surgeon is often cited as the reason why a patient has to be transferred, the true logistical evaluation is always more complex. Surgeons who undertake care have to be prepared to deal with unexpected, difficult intraoperative findings and complex postoperative courses. Adages such as "preparing for the worst is better than hoping for the best" and "the last thing a surgeon learns is when not to operate" have stood the test of time. Good care of residents of remote areas must include close collaboration and 
shared care with their family physician. This requires enhancement of skills over those practised by the urban family physician. It is unlikely that such enhancement would usefully include the addition of major surgery. The curriculum proposed for enhanced surgical skills of a family physician actually describes that of a generalist general surgeon. ${ }^{4}$ The authors of the curriculum proposal have identified a perceived need for surgery in underserviced areas of Canada. Simple dismissal of the proposal will not resolve the concern. The solution will require multilevel discussions about the roles of generalist general surgeons and family physicians with enhanced skills (general practitioners) in an era where super-specialization is threatening care in less populated districts.
Edward J. Harvey, MD; Vivian C. McAlister, MD

Coeditors, Canadian Fournal of Surgery

Competing interests: E.J. Harvey is the Chief Medical Officer of Greybox Healthcare (Montréal) and Chairman of the Board of NXTSens Inc. (Montréal). None declared for V.C. McAlister.

DOI: $10.1503 /$ cjs. 015515

References:

1. Caron N, Iglesias S, Friesen R, et al. A proposal for the curriculum and evaluation for training rural family physicians in enhanced surgical skills. Can 7 Surg 2015;58:419-22.

2. Warnock G, Miles P. Why Canada needs networks to provide rural surgical care, including family doctors with essential surgical skills. Can 7 Surg 2015;58:367-8.

3. Vinden C, Ott MC. GPs with enhanced surgical skills: a questionable solution for remote surgical services Can 7 Surg 2015;58:369-71.

4. Webber EM, McAlister VC, Gorman L, et al. The past and future of the generalist general surgeon. Can 7 Surg 2014;57:6-7.

\section{L'apprentissage interspécialités à l'ère de la formation basée sur les compétences}

Voir les commentaires connexes (en anglais) de Warnock et Miles (p. 367) et de Vinden et Ott (p. 369) ainsi que la discussion en chirurgie (en anglais) de Caron et collaborateurs (p. 419)

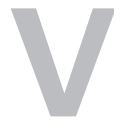

ous pourrez lire dans ce numéro un article au sujet d'une proposition de programme de formation en chirurgie à l'intention des médecins de famille ${ }^{1}$. Nous avons décidé de le publié avec des commentaires connexes pour et contre la proposition en vue de favoriser un débat éclairé. Les tenants de la proposition sont d'avis qu'en améliorant les compétences chirurgicales des médecins de famille, on augmente la possibilité d'offrir des soins chirurgicaux aux patients dans les régions éloignées où il pourrait ne pas y avoir de chirurgiens ${ }^{2}$. Les opposants doutent de la prémisse de la proposition, arguant que les patients des régions éloignées ont un excellent accès aux soins chirurgicaux et s'attendent à recevoir des soins de la même qualité que les patients d'ailleurs ${ }^{3}$.

Cette proposition survient à un moment où la formation spécialisée est en pleine mutation. Au lieu de concevoir un programme de formation comme processus basé sur le temps pour l'acquisition séquentielle de connaissances et de compétences, on suggère que la progression de la formation en chirurgie soit plutôt fondée sur l'acquisition de compétences définies. Le Collège royal des médecins et chirurgiens du Canada a donné à cette transformation l'appellation de « compétence par conception ». Alors que la version actuelle de l'initiative de la compétence par conception s'applique à la formation médicale postdoctorale (résidence), on compte y inclure la formation postcertification qui porte actuellement la désignation de « développement professionnel continu » (DPC). La compétence par conception permettra entre autres aux chirurgiens de personnaliser leur formation en fonction des exigences de pratique de leurs situations particulières. Certains chirurgiens limiteront leur pratique à des secteurs d'intérêt spécialisé (p. ex., arthroplastie ou chirurgie hépatobiliaire); d'autres suivront une formation interspécialité afin d'élargir leurs compétences (p. ex., césarienne effectuée par des chirurgiens généraux). Où donc, à l'ère de la compétence par conception, s'inscrit cette proposition visant à former les médecins de famille pour leur permettre d'effectuer des chirurgies lourdes?

La compétence par conception supprime l'élément de temps, sans modifier les autres éléments fondamentaux de la formation. Les modules de cours comportent tous 4 éléments : prérequis, phase d'apprentissage, examens et maintien des compétences. Actuellement, les prérequis pour qu'un stagiaire suive une formation chirurgicale avancée sont la réussite des cours et des examens portant sur les principes de chirurgie. Il faudrait accorder certains crédits aux médecins de famille certifiés, mais la proposition devrait inclure une formation supplémentaire ainsi que des examens portant sur les principes fondamentaux de la chirurgie afin de répondre à la norme validée des prérequis. La compétence par conception 